\title{
Criticality Studies of a Neutron Multiplier Lattice
}

by

R. C. Lloyd, S. R. Bierman,

E. D. Clayton and B. M. Durst

April 1976

Prepared for the Energy Research and Development Administration under Contract E(45-1):1830 
NOTICE

This report was prepared as an account of work sponsored by the United States Covernment. Neither the United States nor the Energy Research and Development Administration, nor any of their employees, nor any of their contractors, subcontractors, or their employees, makes any warranty, express or implied, or assumes any legal liability or responsibility for the accuracy, completeness or usefulness of any imformation, apparatus, product or process disclosed, or represents that its use would not infringe privately owned rights.

PACIFIC NORTHWEST LABORATORY

operated by

BATTELLE

for the

ENERGY RESEARCH AND DEVELOPMENT ADMINISTRATION

Under Contract E(45-1)-1830

Printed in the United States of America Available from

Vational Technical Information Service

U.S. Department of Commerce

5285 Port Royal Road

Springfield, Virginia 22151

Price: Printed Copy \$5.00; Microfiche \$2.25 


\section{9}

UC -46

CRITICALITY STUDIES OF A NEUTRON

MULTIPLIER LATTICE

by

R. C. Lloyd, S. R. Bierman

E. D. Clayton, B. M. Durst

Apri1 1976

Battelle

Pacific Northwest Laboratories

Richland, Washington 99352 


\section{TABLE OF CONTENTS}

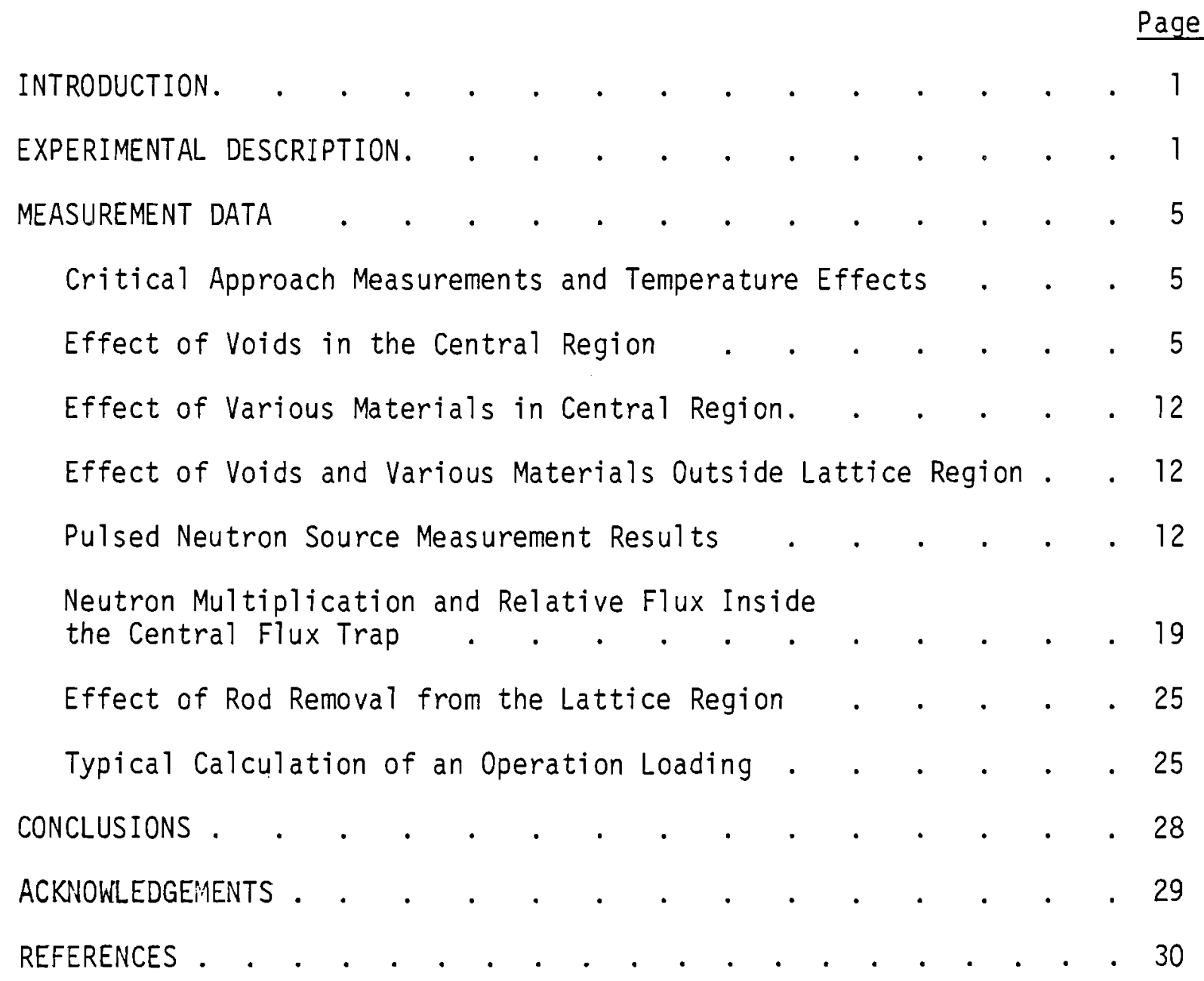




\section{CRITICALITY STUDIES OF A NEUTRON MULTIPLIER LATTICE}

R. C. Lloyd, S. R. Bierman, E. D. Clayton, B. M. Durst

\section{INTRODUCTION}

There has been considerable need for neutron radiation units with high neutron yield. $(1,2)$ Sources of various types have been used for this purpose for many years, but have lacked the intensity and volume, with level flux, for larger sample irradiation. While the research reactor can produce desirable neutron flux, the operation is rather costly. A neutron multiplier has been designed using a subcritical lattice of enriched uranium rods with a central cylindrical flux trap. $(3,4)$. This lattice unit was loaded at the Critical Mass Laboratory to study aspects of criticality including temperature, voids, and added material. Data from these experiments are presented in this report.

\section{EXPERIMENTAL DESCRIPTION}

The experimental system consisted of a lattice assembly, reflected and moderated with water, in a cylindrical tank having a diameter of $102 \mathrm{~cm}$. Measurements were made at lattice spacings of 0.55 and 0.60 inch. A photograph of the assembly is shown in Fig. 1. The canned fuel rods were a $I+A 1$ alloy having a ${ }^{235} \mathrm{U}$ enrichment of $93.2 \mathrm{wt} \%$; they were 0.40 inch in diameter and 23-3/4 inches in length. Detailed dimensions are shown in Fig. 2.

The lattices were safely loaded, using the critical approach method; this also provided the extrapolation for the critical number of rods. At selected fuel loadings, pulsed neutron source measurements were made to determine reactivity and prompt neutron decay rates. The effect of voids and various materials placed in the central region and outside the loaded lattice was measured in terms of the number of rods required for criticality. Dimensions of these materials are given in Table I. To measure the reactivity 


\section{FUEL ROD}

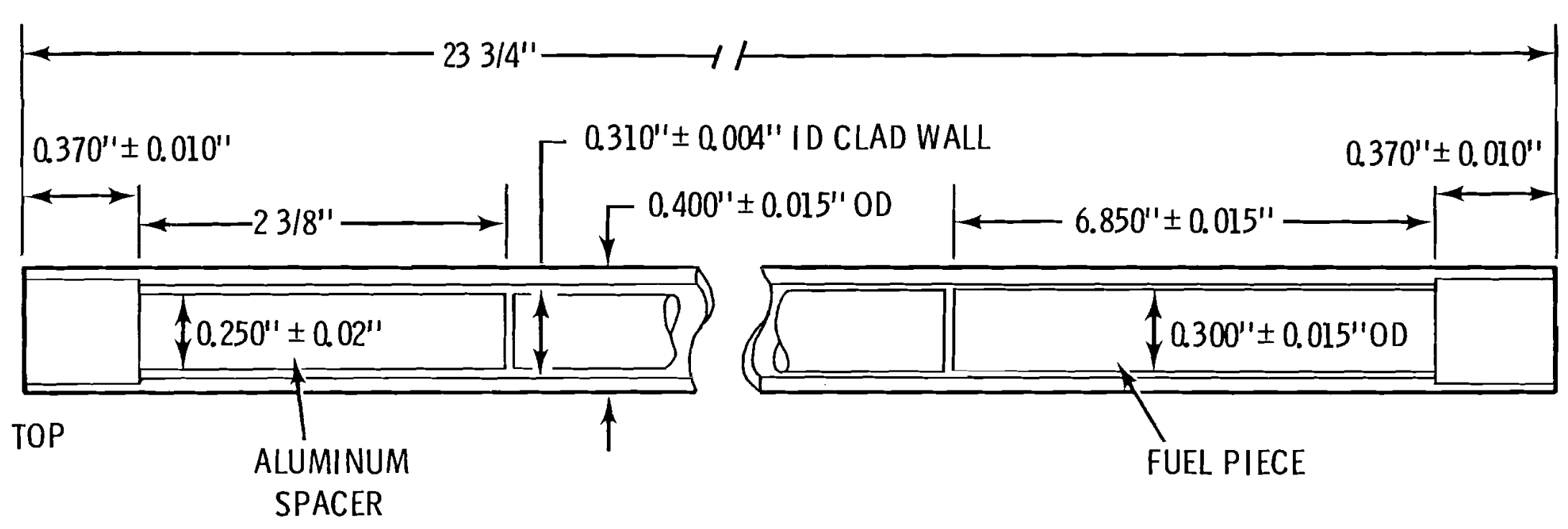

CLAD MATERIAL: ALUMINUM, 1100

LOAD MATERIAL: 28 W/O U IN AI, $93.2 \mathrm{w} / 0^{235} \mathrm{U}$ IN U, $1 \mathrm{am} \mathrm{U}(93.2) / \mathrm{cm}^{3}$. 3 FUEL PIECES PER ROD. $22.224 \mathrm{gm}$ 235U PER ROD 
TABLE I

TEST MATERIAL DETAILS

Material

Al Void Tubes

Al Void Tubes

Al Void Tubes

A1 Void Tubes

Graphite Rod

Plexiglas Rod

Wood Dowel

Bi Metal (grannular)

Mineral $0 i 1$
Dimensions

1.00 in. $00 \times 0.063$ in. wall

2.00 in. $00 \times 0.063$ in. wall

3.00 in. $00 \times 0.094$ in. wall

5.00 in. $00 \times 0.094$ in. wall

1.75 in. diam, $1.65 \mathrm{~g} / \mathrm{cc}$

1.25 in. diam, $1.18 \mathrm{~g} / \mathrm{cc}$

$1.25 \mathrm{in.} \mathrm{diam,} 0.72 \mathrm{~g} / \mathrm{cc}$

1.341 in. ID, 1.401 in. OD A1 tube, $5.44 \mathrm{~g} / \mathrm{cc}$

1.341 in. ID, 1.401 in. OD A1 tube 
effect of temperature, the water was heated using an electrical calrod unit and a steam coil. Temperatures were monitored using thermocouples, and the number of rods required for criticality was determined as a function of water temperature.

MEASUREMENT DATA

Critical Approach Measurements and Temperature Effects

Critical approach measurements were carried out for the 0.55 and $0.60 \mathrm{in}$. lattice spacings at room temperature $\left(\sim 21^{\circ} \mathrm{C}\right)$ and for the $0.60 \mathrm{in}$. lattice at temperatures up to $71^{\circ} \mathrm{C}$. Table II and Fig. 3 show the results of these critical approach measurements made at various temperatures with the $0.60 \mathrm{in}$. lattice. The critical number of fuel rods at $21^{\circ} \mathrm{C}$, with a $2 \mathrm{in}$. central void and a 37 rod equivalent flux trap, was 271.4. The same system with the 2 in. diameter central tube half filled with water was 276.3. When either system was heated, the maximum decrease in critical number of rods, heating from $21^{\circ} \mathrm{C}$, was about 2.6, while the system having the 2 in. diameter void leveled off at a somewhat lower temperature.

The $0.55 \mathrm{in}$. lattice spacing showed a critical number of rods to be 340.9 with a 37 cell flux trap, and 360.2 with a 55 cell flux trap. Both lattices had a 2 in. central void.

Effect of Voids in the Central Region

Table III shows the worth of voids in the central region of the $0.55 \mathrm{in}$. laticice in terms of the effect on the critical number of rods. Fig. 4 shows the void effect in the $0.55 \mathrm{in}$. lattice with both the 37 and 55 cel1 flux traps. The minimum appears to occur slightly above $30 \%$. Table IV lists the critical number of rods for the $0.60 \mathrm{in}$. lattice with various void tubes in the central region. Fig. 5 shows the critical number of rods as the void percent in the 


\section{TABLE II}

\section{CRITICALITY OF NEUTRON MULTIPLIER 0.60 IN. LATTICE \\ (EFFECT OF TEMPERATURE CHANGE)}

\begin{tabular}{|c|c|c|c|c|}
\hline $\begin{array}{l}\text { Exp. } \\
\text { No. }\end{array}$ & $\begin{array}{l}\text { Temperature } \\
\left(C^{O}\right)\end{array}$ & $\begin{array}{c}\mathrm{N}_{\mathrm{c}} \\
\text { (Rods) } \\
\end{array}$ & $\begin{array}{l}\text { Max. Temp. } \\
\text { Effect } \\
\text { (Rods) } \\
\end{array}$ & Condition \\
\hline 007 & 21 & 271.42 & & $\begin{array}{l}2 \text { in. Diam. Center Void, } \\
37 \text { Rod Equivalent Flux Trap }\end{array}$ \\
\hline 010 & 32 & 269.08 & 2.62 & \\
\hline 011 & 50 & 268.80 & & \\
\hline 012 & 71 & 269.17 & & \\
\hline 015 & 23 & 276.25 & & $\begin{array}{l}2 \text { in. Diam. Center Void - } \\
\text { l/2-filled with } \mathrm{H}_{2} \mathrm{O} \\
37 \text { Rod Equivalent } \\
\text { Flux Trap }\end{array}$ \\
\hline 017 & 47 & 273.73 & 2.61 & \\
\hline 018 & 70 & 273.64 & & \\
\hline
\end{tabular}




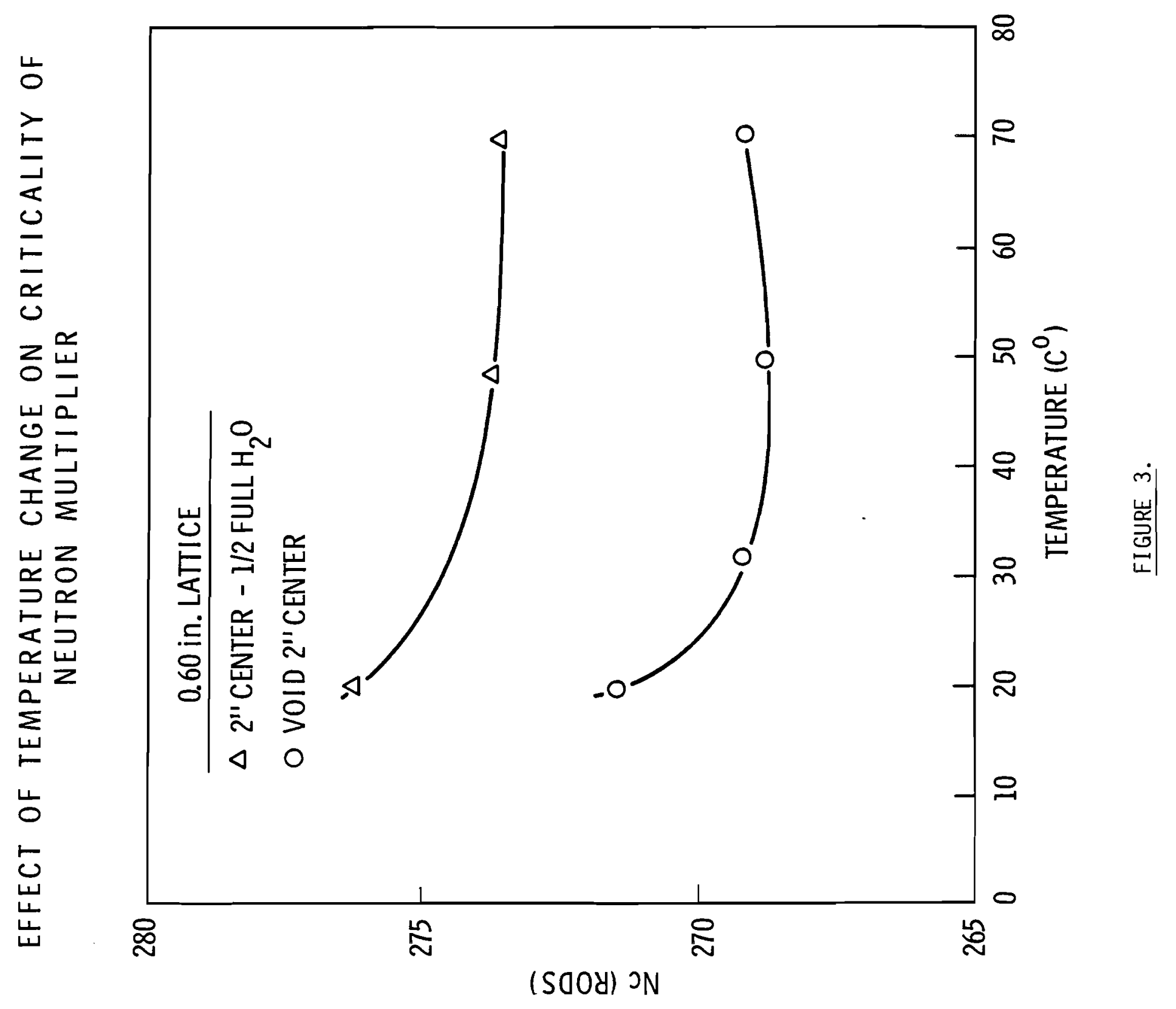




\section{TABLE III.}

CENTER VOID EFFECT AS A FUNCTION OF CHANGE IN THE FLUX TRAP SIZE

(0.55 IN. LATTICE)

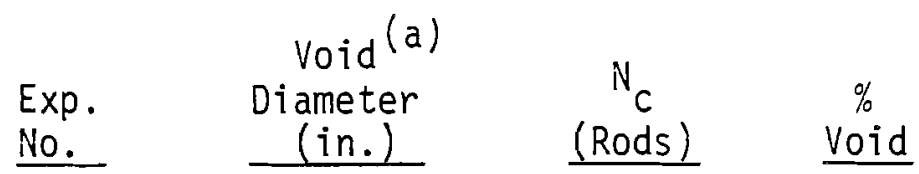

(37 Tube Flux Trap)

$\begin{array}{cccc}001 \mathrm{~A} & 0 & 348.43 & 2.64 \\ & 1 & 345.80 & 8.10 \\ 2 & 341.76 & 32.4 \\ & 3 & 371.91 & 72.9\end{array}$

(55 Tube Flux Trap)

$\begin{array}{cccc}002 \mathrm{~A} & 0 & 374.74 & 3.92 \\ & 2 & 360.38 & 21.8 \\ & 3 & 361.52 & 49.1\end{array}$

a. 0 void diameter was measured by filling the 2 in. Al center tube with water. Al assumed as void in \% void calculation. 
EFFECT OF CENTER VOIDS

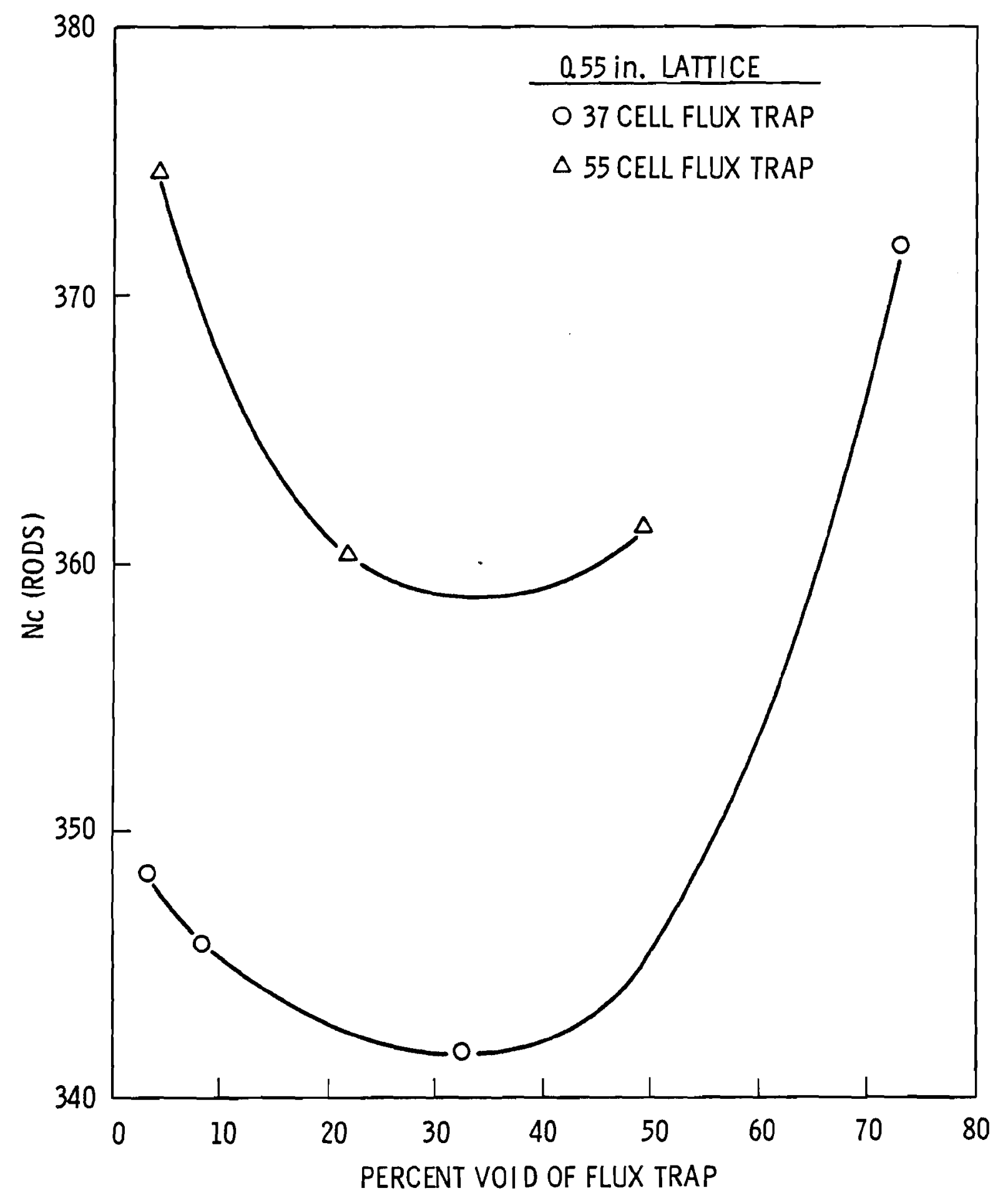

FIGURE 4. 


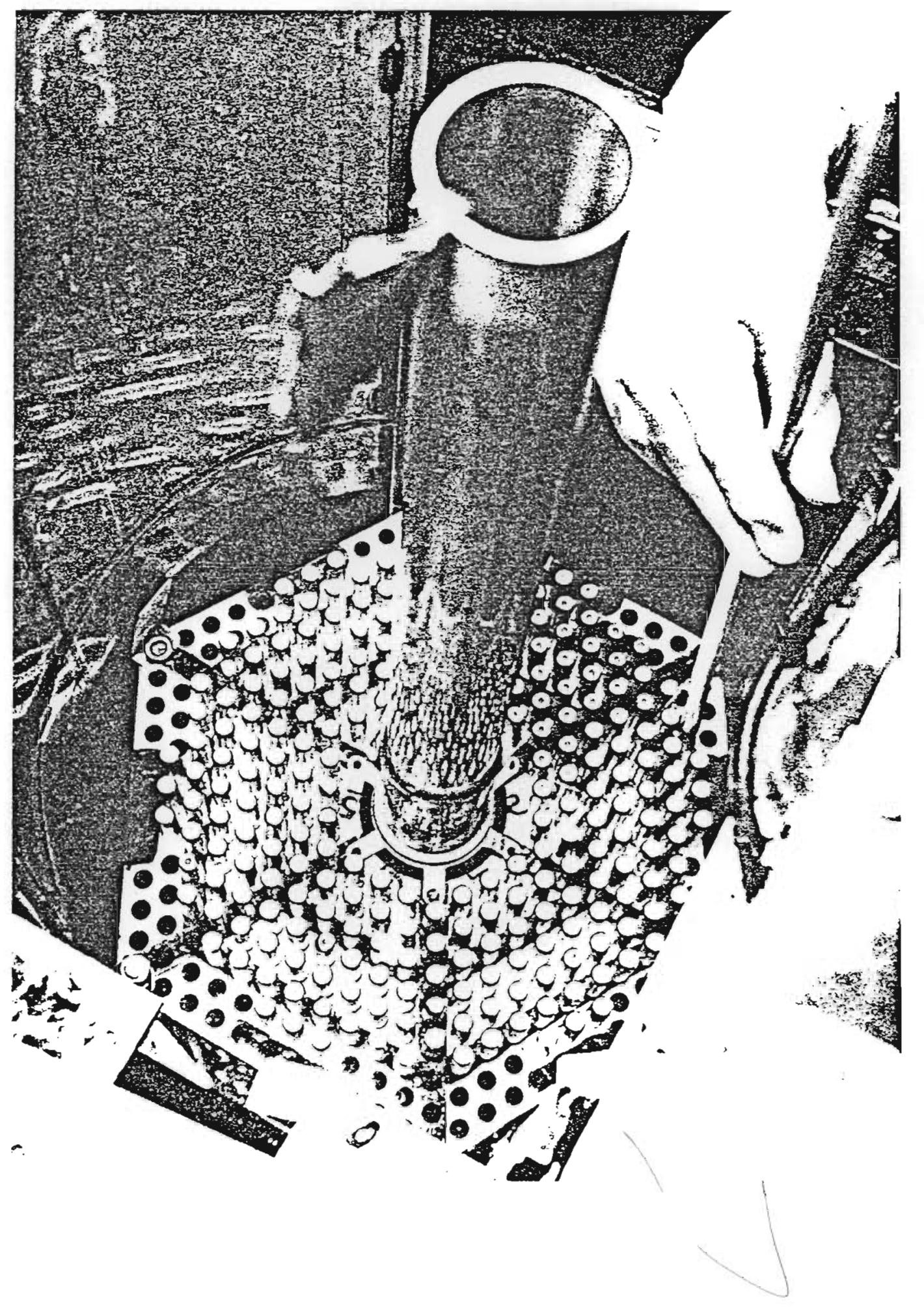

FIGURE 1 
TABLE IV.

CENTER VOID EFFECT AS A FUNCTION OF TEMPERATURE (0.60 IN. LATTICE)

\begin{tabular}{lccc} 
& Void (a) & & \\
Exp. & Diameter & $N_{C}$ & $\%$ Void \\
No. & (in.) & (Rods) & \\
\hline
\end{tabular}

$\left(21^{\circ} \mathrm{C}\right.$ Temperature $)$

$\begin{array}{cccc}009 & 281.87 & 3.30 \\ 1 & 278.69 & 6.81 \\ 2 & 271.35 & 27.2 \\ 3 & 280.64 & 61.3\end{array}$

$\underline{\left(74^{\circ} \mathrm{C} \text { Temperature) }\right.}$

$\begin{array}{cccc}013 & 275.12 & 3.30 \\ 1 & 273.16 & 6.81 \\ 2 & 268.95 & 27.2 \\ 3 & 280.70 & 61.3\end{array}$

a. 0 void diameter was measured by filling the 2 in. Al center tube with water. Al assumed as void in \% void calculations. 
EFFECT OF CENTER VOIDS

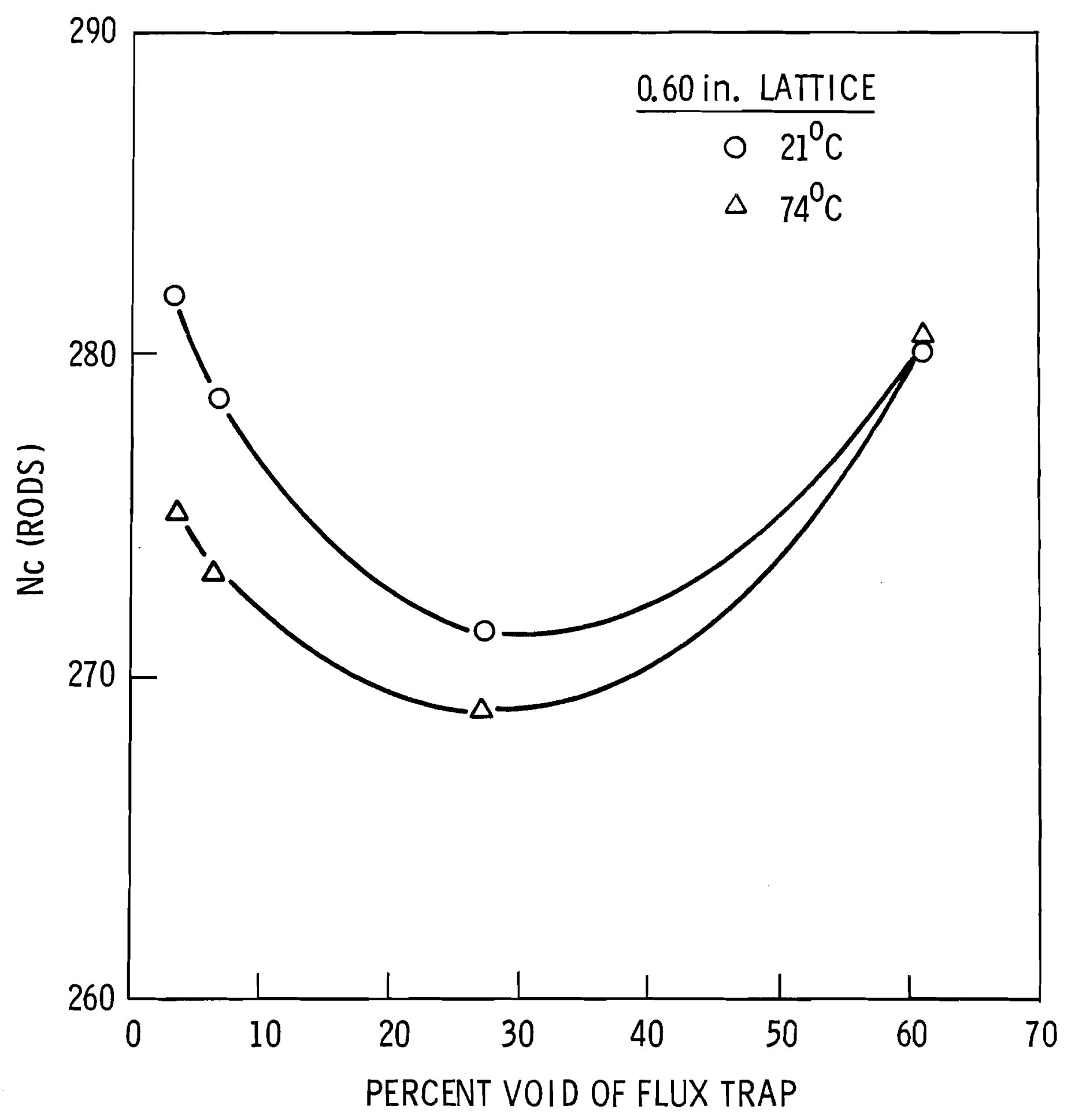

FIGURE 5. 
BNWL-2031

flux trap increases. Here, the minimum critical number of rods occurs at slightly less than $30 \%$ void.

\section{Effect of Various Materials in Central Region}

To determine the sensitivity of critical number of rods to materials being placed in the flux trap region (such as would occur during use of the multiplier), various materials were placed in the central region. Table $V$ gives the worth of these various materials, in terms of rods, on reactivity increase or decrease. The $1 / 3$ fue 1 rod had a worth of +4.4 fuel rods, the 1-3/4 in. OD graphite rod was the equivalent of +3.3 and the source mockup was -1.9. These materials were positioned as they would be in normal usage. To get a maximum ability to reduce reactivity, a 2 in. void was filled with an aqueous $6 \mathrm{~g}$ boric acid $\left(\mathrm{H}_{3} \mathrm{BO}_{3}\right) / 1$ iter solution, providing about a 29 rod reduction. In actual usage, where only half the center hole would be available to add poison, the effect of this central poison would be reduced by $50 \%$.

Effect of Voids and Various Materials Outside Lattice Region

Knowledge of the effect of irradiation tubes outside the lattice is needed for operation of the multiplier; also, the effect of various materials that might be inserted in these tubes. The effects that were measured are given in Table VI. A cylindrical void (empty aluminum tube) placed against the lattice plate had a considerable negative reactivity worth of about 2.3 rods for the 2 in. diameter tube and about 6 rods for the $5 \mathrm{in}$. diameter tube. It is also of interest that adding a 1-3/4 in. diameter graphite rod in the 2 in. diameter void increased the reactivity by the equivalent of 3.6 fuel rods. Even more interesting is the fact that this is a 1.3 fuel rod increase over having water in that region. Pulsed Neutron Source Measurement Results

Pulsed neutron source measurements were performed on the lattice assembly having a 0.6-inch spacing and a center flux trap equivalent to 37 fuel rods. 


\section{TABLE $V$.}

EFFECT OF MATERIAL IN CENTER TUBE

(Center Tube 1/2-Filled With $\mathrm{H}_{2} \mathrm{O}^{-}=0.60$ in. Lattice Spacing)

Material

1/3 Fuel Rod

1 Fuel Rod

Graphite (1-3/4 in. 00)

Source Mockup (200 g SS)

1.34-in. Tube of Bismuth

$1.34 \mathrm{in}$. Tube of Mineral $0 \mathrm{i}$

$17 \mathrm{Cd}$-Covered Cu Foils

Spaced 2" Vertically

$17 \mathrm{Cu}$ Foils

Spaced 2" Vertically

$6 \mathrm{~g} / \mathrm{e}$ Boric Acid-Filled

2" Void Tube

$\mathrm{BF}_{3}$ Tube
Position

In Void - Above Center

Centered Vertically

In Void in Top Half

In Water In Bottom Half

In Void in Top Half

In Void in Top Half

Centered Vertically

Centered Vertically

Centered Vertically

Centered Vertically
Reactivity Worth

(Fuel Rods)

$+4.37$

$+11.46$

$+3.29$

$-1.86$

$+0.87$

$-2.40$

$-6.68(a)$

$-1.68^{(a)}$

-29.1 (b)

$-1.48^{(b)}$

a. Part of effect due to change in water height in center tube.

b. Center tube completely void of $\mathrm{H}_{2} \mathrm{O}$. 


\section{TABLE VI.}

EFFECT OF OUTSIDE LATTICE VOID TUBES AND MATERIAL

\begin{tabular}{|c|c|c|}
\hline $\begin{array}{l}\text { Void } \\
\text { Diameter } \\
\end{array}$ & \multicolumn{2}{|c|}{$\begin{array}{l}\text { (Center Tube 1/2-Filled With } \mathrm{H}_{2} \mathrm{O}-0.60 \mathrm{in.} \text { Lattice Spacing) } \\
\text { er } \quad \text { Reactivity Worth (b) } \\
\text { Placement Description }\end{array}$} \\
\hline 2 in. & Flush to Lattice Plate ${ }^{(a)}$ & -2.13 \\
\hline 2 in. & 1 in. from Lattice Plate & -0.53 \\
\hline 2 in. & 2 in. from Lattice Plate & -0.09 \\
\hline 5 in. & Flush to Lattice Plate & -5.97 \\
\hline 2 in. & $\begin{array}{l}\text { Void Filled with Graphite Rod }(1-3 / 4 \text { in. }) \\
\text { Flush to Lattice Plate Compared to Void }\end{array}$ & +3.63 \\
\hline 2 in. & $\begin{array}{l}\text { Void Filled with Graphite Rod Flush to } \\
\text { Lattice Plate }\end{array}$ & +1.25 \\
\hline 2 in. & Flush to Lattice Plate (Recheck) & -2.38 \\
\hline 2 in. & Flush to Lattice Plate (Recheck) & -2.40 \\
\hline 2 in. & $\begin{array}{l}\text { Void/1.34 Tube Mineral } 0 i 1 \\
\text { Flush to Lattice Plate }\end{array}$ & -0.90 \\
\hline 2 in. & $\begin{array}{l}\text { Void/1.34 Tube Bismuth } \\
\text { Flush to Lattice Plate }\end{array}$ & -1.31 \\
\hline 2 in. & $\begin{array}{l}\text { Void/ } 1-1 / 4 \text { in. Wood } \\
\text { Flush to Lattice Plate }\end{array}$ & -1.37 \\
\hline 2 in. & $\begin{array}{l}\text { Void/1-1/4 in. Plexiglas } \\
\text { Flush to Lattice Plate }\end{array}$ & -0.81 \\
\hline 2 in. & $\begin{array}{l}\text { Void Tube of Mineral 0il } \\
\text { Flush to Lattice Plate }\end{array}$ & +0.06 \\
\hline
\end{tabular}

a. Edge of lattice plate to edge of fuel loading was $0.690 \mathrm{in}$.

b. A11 worths compared to water except as noted with the graphite rod. 
The measurements were conducted at room temperature $\left(\sim 21^{\circ} \mathrm{C}\right)$ and with the $2-i n$. void tube axially through the center of the flux trap. The pulsed neutron source was positioned in the reflector region away from the fuel rods with its tritium target at the mid-plane of the lattice. Two neutron detectors were used, independently, for data accumulation. The primary detector, a $\mathrm{BF}_{3}$ tube, was located at the center of the lattice in the $2-i n$. void tube to minimize spatial effects in the data. However, as the delayed critical condition was approached, a secondary neutron detector (a boron-lined proportional counter), located in the reflector region opposite the pulsed neutron source, had to be relied upon for data accumulation.

Measurement data were obtained on five symmetrical fue 1 rod loadings nearest the delayed critical loading as predicted by the companion critical approach measurements. Each set of data was least squares fit to a single exponential term plus a constant to determine the prompt neutron decay rate for each fuel loading. Each set of data was also analyzed using the GarelisRusse11 ${ }^{(5)}$ method and the Gozani ${ }^{(6)}$ method to determine the reactivity of each fuel loading. The results of these data analyses are shown graphically in Fig. 6. Experimentally determined corrections of about $0.5 \%$ in mass were applied to all the measurement results to account for the presence of the pulsed neutron source system. The number of fuel rods required for criticality was 271.42 without the pulsed neutron system and 272.9 with it in position.

As expected, no spatial effects were observed in the prompt neutron decay rates. Data from both detectors yielded decay rates which varied linearly over the fuel loading range, with no apparent dependency on the data source. By linearly extrapolating these subcritical data to the prompt critical condition, a prompt critical loading of 281.5 fuel rods is obtained. 
BNWL-2031

PULSED NEUTRON SOURCE MEASUREMENT RESULTS - NEUTRON MULTIPLIER LATTICE

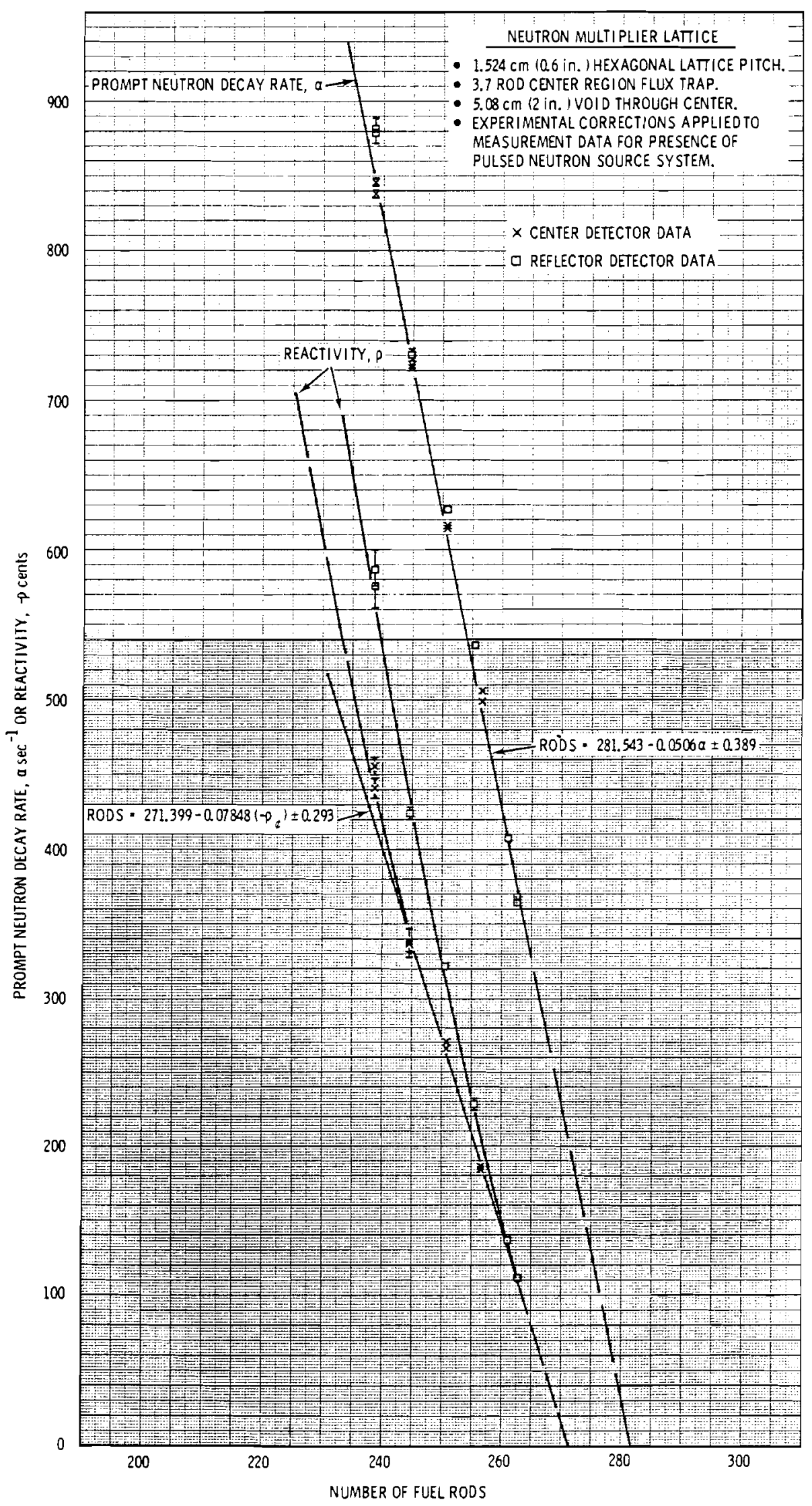

FIGURE 6. 
Not unexpectedly, some spatial effects were observed in the reactivity analyses of these measurement data. As shown in Figure 6 , analyses of the data accumulated with the detector located in the reflector region gives different reactivity values from those obtained from the data accumulated with the detector located in the center of the fuel lattice. However, as the delayed critical condition is approached, the reactivity values converge such that the data from the reflector detector gives the same value for the reactivity of the largest subcritical fuel loading as does an extrapolation of the data from the center detector. By extrapolating this subcritical data to the delayed critical condition, a delayed critical loading of 271.4 fuel rods is obtained.

By comparing the differences between the prompt critical loading and the delayed critical loading, a reactivity worth of 9.9 cents per rod can be determined for the fuel rods near the critical loading. This is equivalent to 0.00065 per rod in terms of the neutron multiplication constant ( $k_{\text {eff }}$ ) if a reasonable value of 0.0065 is assumed for the effective delayed neutron fraction ( $\beta_{\text {eff }}$ ).

Effective neutron multiplication constants $\left(k_{\text {eff }}\right)$ have been determined from the reactivity data shown in Figure 6 by assuming a value of 0.0065 for $\beta_{\text {eff. }}$. These $k_{\text {eff }}$ values as a function of fuel rod loading are shown graphically in Figure 7. A curve is also shown in Figure 7 depicting the reactivity effect resulting from filling the lower half of the center void tube with water. This second curve was obtained by considering that filling the void tube half full of water increases the number of fuel rods required for criticality by 4.9 rods and by applying the rod worth of $0.65 \mathrm{milli-k}$ uniformly over the lattice loadings shown. 
$k_{\text {eff }}$ FROM PULSED NEUTRON SOURCE MEASUREMENTS - NEUTRON MULTIPLIER LATTICE

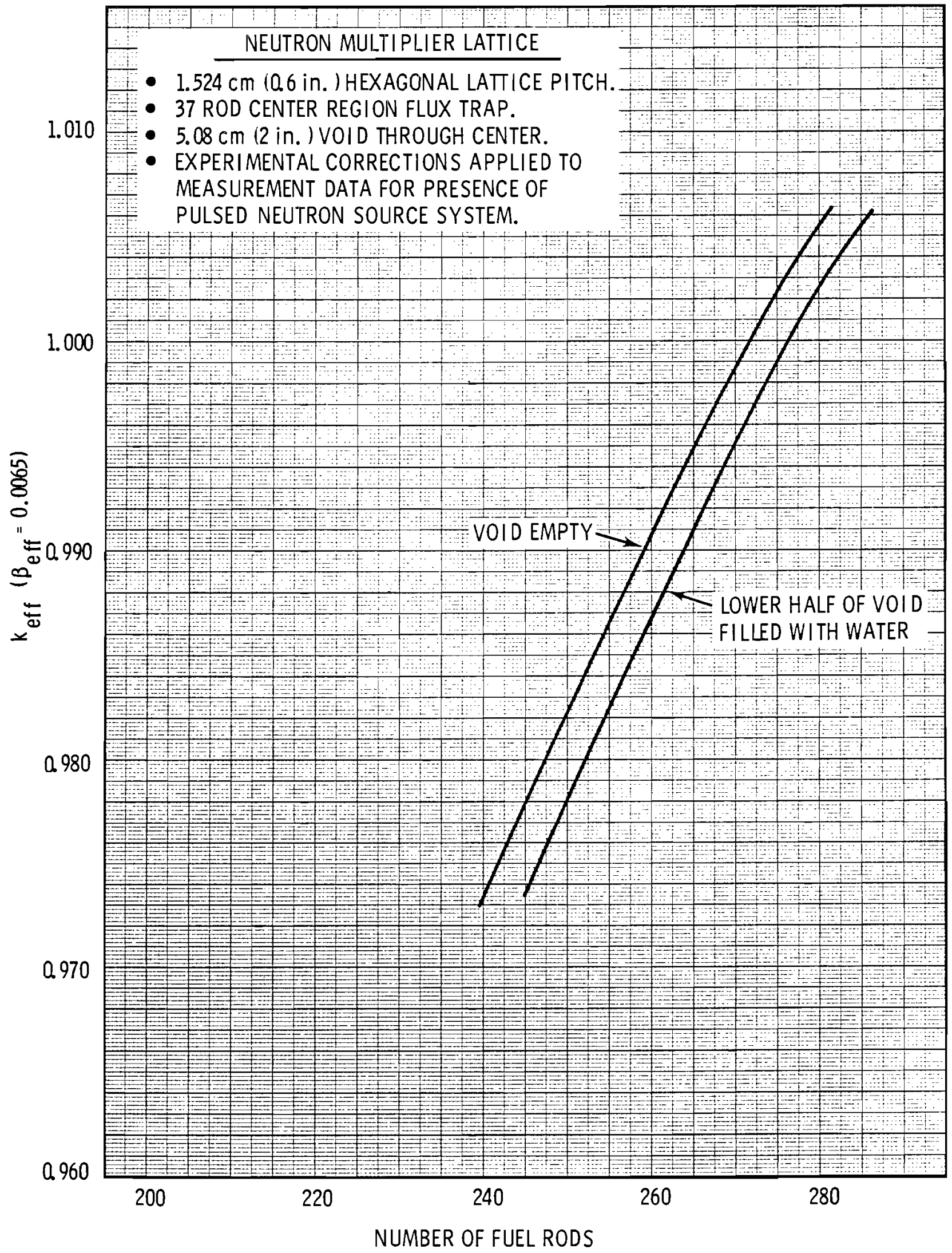


Neutron Multiplication and Relative Flux Inside the Central Flux Trap

A study was made of relative neutron flux levels inside the central flux trap of the multiplier using the arrangement shown in Figure $8 .(7,8)$ Seventeen small copper foils ( $3 / 8 \mathrm{in} .0 \mathrm{D}, \sim 0.16 \mathrm{gm})$ were vertically inserted into the flux trap at $2 \mathrm{in}$. increments above and below the ${ }^{252} \mathrm{Cf}$ source. Axial traverse data were obtained for both bare and cadmium-covered foils with and without the fuel in place. The source was positioned alongside of the 2 in. flux trap tube at the midpoint height of the fuel region. Half of the foils were, therefore, exposed in air and half in water. From these data, the thermal neutron multiplication of the multiplier was then determined by:

$$
M=\frac{(\text { bare activity }-C d \text { activity) fuel }+ \text { source }}{\text { (bare activity }- \text { Cd activity) source only }}
$$

With the multiplier loaded to 264 rods and operating at a $k_{\text {eff }}=\sim 0.991$ the thermal multiplication is $\sim 20$ (see Table VII). The multiplier greatly enhances and broadens the axial flux profile (see Fig. 9). In the water region of the flux trap (below the source), the flux follows fairly well $\phi(z) \sim 49 \cos (0.121 z)$ (see Fig. 10). An upward flux tail is observed below the fuel, probably due to neutron reflection by the water. In the air side of the flux trap, the thermal flux can be seen to closely follow a profile of $\phi(z) \sim 49 e^{-0.1 z}$ between the fuel center and top. Above the fuel, the flux falls off linearly, probably due to neutron streaming from the void. The peak thermal flux occurs slightly below the center point due to the moderation and reflection by the water. The peak total flux also occurs here.

Table VIII displays a comparison of relative flux levels radialiy from the center point of the multiplier. One foil was placed in water $\sim 1.8$ in away from 


\section{FLUX TRAVERSE EXPERIMENT SETUP}

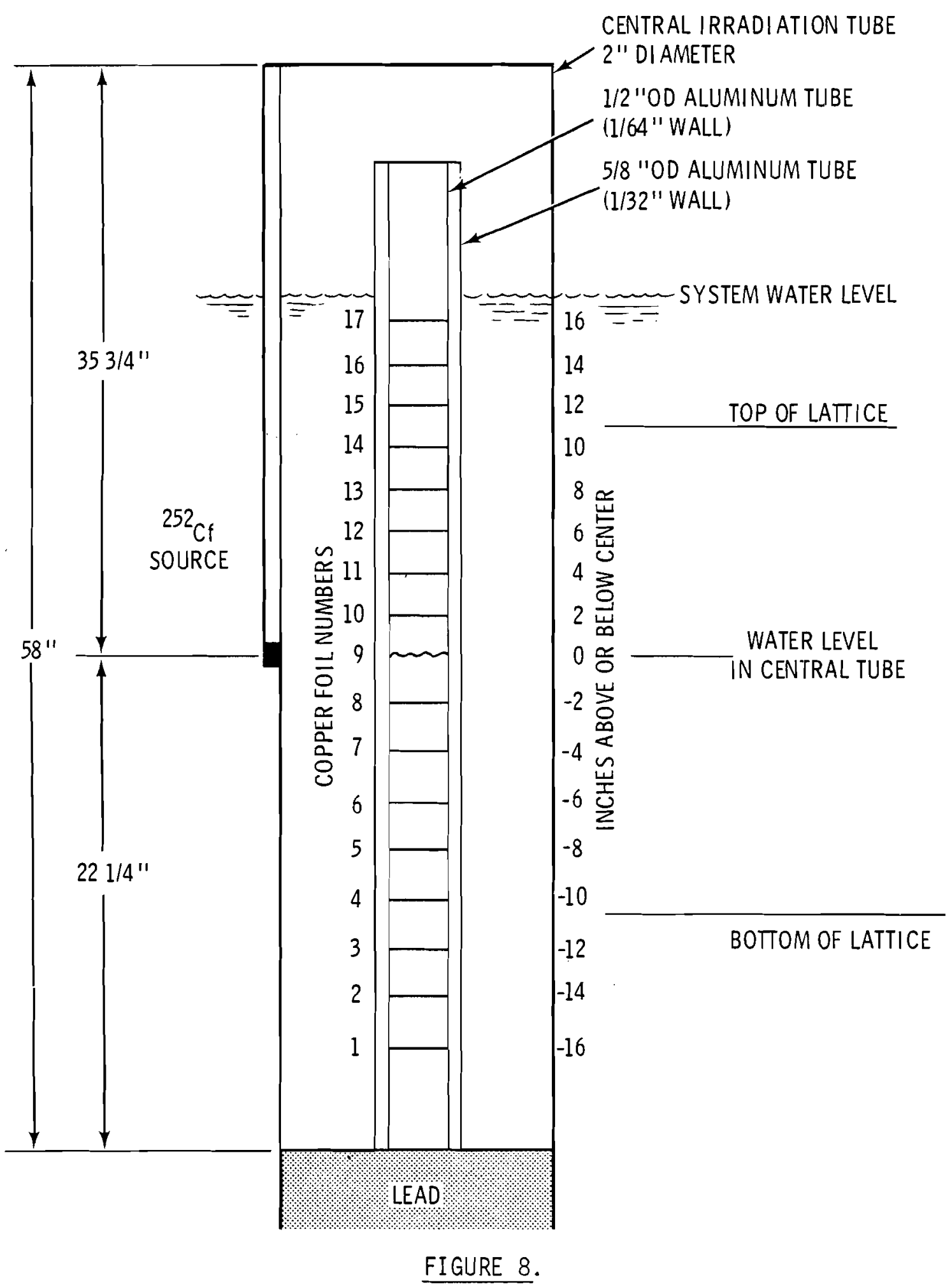


TABLE VII

RESULTS OF CENTRAL FLUX TRAP FOIL IRRADIATION ${ }^{1)}$

\section{(0.60 Lattice Spacing)}

\begin{tabular}{|c|c|c|c|c|c|c|c|c|c|c|c|}
\hline $\begin{array}{l}\text { Vert. Dist. } \\
\text { Foll from Ce } \\
\text { of Flux Irap } \\
\text { +Above } \\
\text {-Below } \\
\end{array}$ & $\begin{array}{l}\text { of } \\
\text { inter } \\
(\mathrm{cm})\end{array}$ & $\begin{array}{l}264 \text { Rods }+ \text { Source } \\
\text { Bare Cu Foils } \\
\text { Sat. Act. } \\
\text { (cpm/gm) } \\
\end{array}$ & $\begin{array}{l}264 \text { Rods+Source 2) } \\
\text { Cd Covered Folls } \\
\text { Sat. Act. } \\
\text { (cpm/gn) } \\
\end{array}$ & Bare/cd & $\begin{array}{c}264 \text { Rods+Source } \\
\text { Bare -cd } \\
\text { Sat. Act. } \\
\text { (cpm/gm) } \\
\end{array}$ & $\begin{array}{l}\text { Source Only } \\
\text { Bare Cu folls } \\
\text { Sat. Act. } \\
\text { (cpm/gm) } \\
\end{array}$ & $\begin{array}{l}\text { Source Only } \\
\text { Cd Covered Folls } \\
\text { Sat. Act. } \\
(\text { cpm } / \mathrm{gm}) \\
\end{array}$ & Bare $/ C d$ & $\begin{array}{l}\text { Source Only } \\
\text { Bare -Cd } \\
\text { Sat. Act. } \\
\text { (cpm/gm) } \\
\end{array}$ & $\begin{array}{c}\text { Bare -Cd } \begin{array}{c}264 \text { Rods } \\
\text { + Source }\end{array} \\
\text { Bare -Cd Source } \\
\text { Thermal Only } \\
\text { Mult1plication }\end{array}$ & $\begin{array}{l}\begin{array}{r}264 \text { Rods } \\
\text { Cd }+ \text { Source }\end{array} \\
\text { cd Source } \\
\text { Fast Only } \\
\text { Multiplication }\end{array}$ \\
\hline-40.64$)$ & & 1910 & 30 & 63.7 & 1880 & 5 & & & & & \\
\hline-35.56 & & 5383 & 100 & 53.8 & 5283 & 9 & & & & & \\
\hline-30.48 & & 10992 & 250 & 44.0 & 10742 & 19 & & & & & \\
\hline-25.40 & 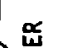 & 17361 & 460 & 37.7 & 16901 & 32 & & & & & \\
\hline-20.32 & 高 & 28396 & 780 & 36.4 & 27616 & 103 & & & & & \\
\hline-15.24 & & 36654 & 1210 & 30.3 & 35444 & 329 & 3 & 110 & 324 & 109 & 242 \\
\hline-10.16 & & 45631 & 1600 & 28.5 & 44031 & 928 & 11 & 84.4 & 917 & 48.0 & 145 \\
\hline-5.08 & & 51350 & 1710 & 30.0 & 49640 & 2198 & 31 & 70.9 & 2167 & 22.9 & 55.2 \\
\hline 0.0 & & 50807 & 1750 & 29.0 & 49057 & 2519 & 75 & 33.6 & 2444 & 20.1 & 23.3 \\
\hline 5.08 & & 38311 & 1730 & 22.1 & 36581 & 1965 & 35 & 56.1 & 1930 & 19.0 & 49.4 \\
\hline 10.16 & & 33082 & 1630 & 20.3 & 31452 & 1140 & 18 & 63.3 & 1122 & 28.0 & 90.6 \\
\hline 15.24 & & 27330 & 1350 & 20.2 & 25980 & 523 & 8 & 65.4 & 515 & 50.4 & 169 \\
\hline 20.32 & $\simeq$ & 21351 & 980 & 21.8 & 20371 & 343 & & & & & \\
\hline 25.40 & & 15657 & 670 & 23.4 & 14987 & 285 & & & & & \\
\hline 30.48 & & 11530 & 370 & 31.2 & 11160 & 91 & & & & & \\
\hline 35.56 & & 7636 & 170 & 44.9 & 7466 & 44 & & & & & \\
\hline 40.64 & & 3335 & 80 & 41.7 & 3255 & 24 & & & & & \\
\hline \multicolumn{12}{|c|}{$\begin{array}{l}\text { 1) All counts are normalized to count rates observed before foils } \\
\text { were inserted into multiplfer } \\
\text { 2) Cadmium activities were re-evaluated by curve fit through the } \\
\text { cadmium foil data. }\end{array}$} \\
\hline
\end{tabular}


BIIWL-2031

RELATIVE FLUX VERSUS AXIAL HEIGHT IN CENTER FLUX TRAP

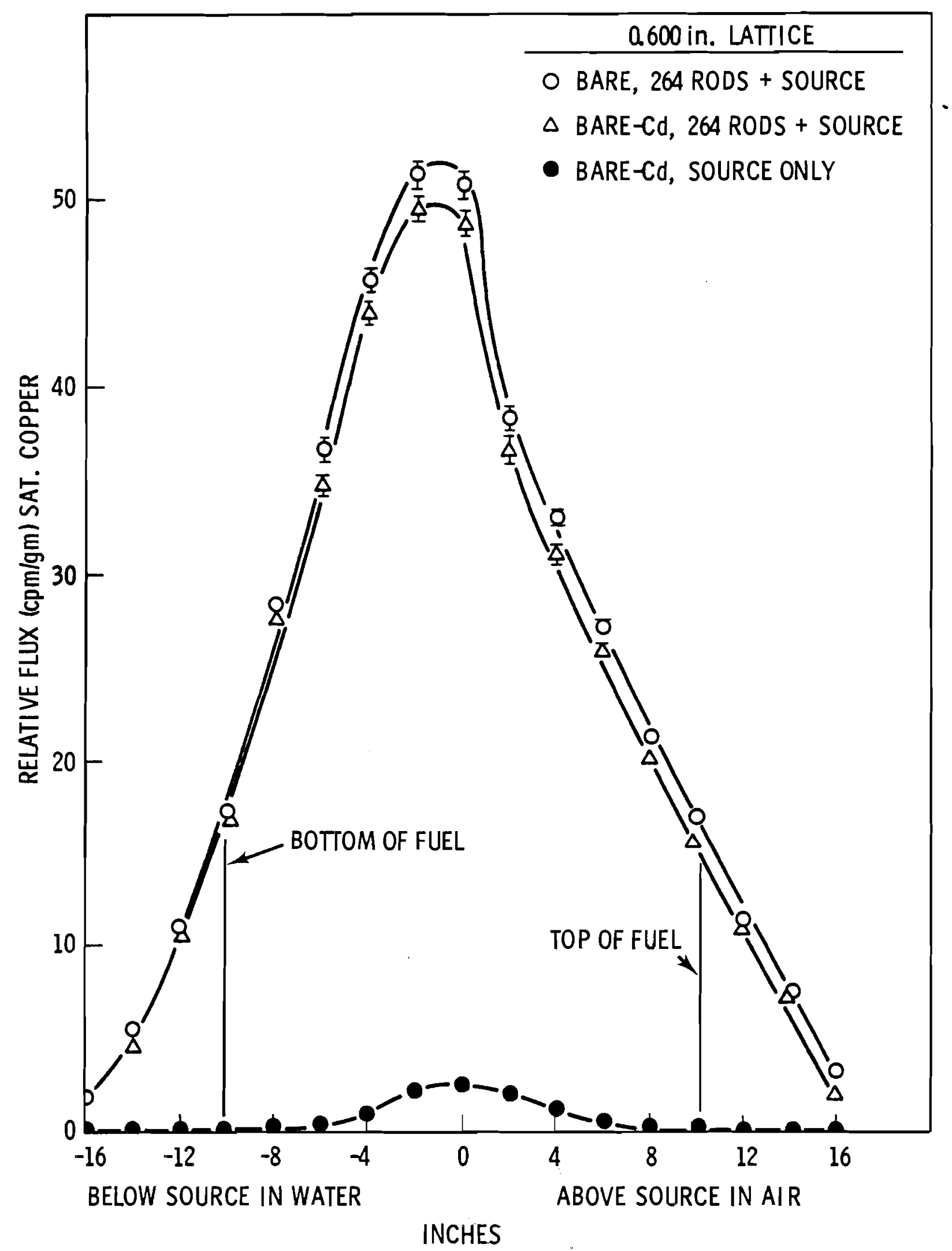

FIGURE 9. 
RELATIVE FLUX VERSUS AXIAL HEIGHT IN CENTER FLUX TRAP

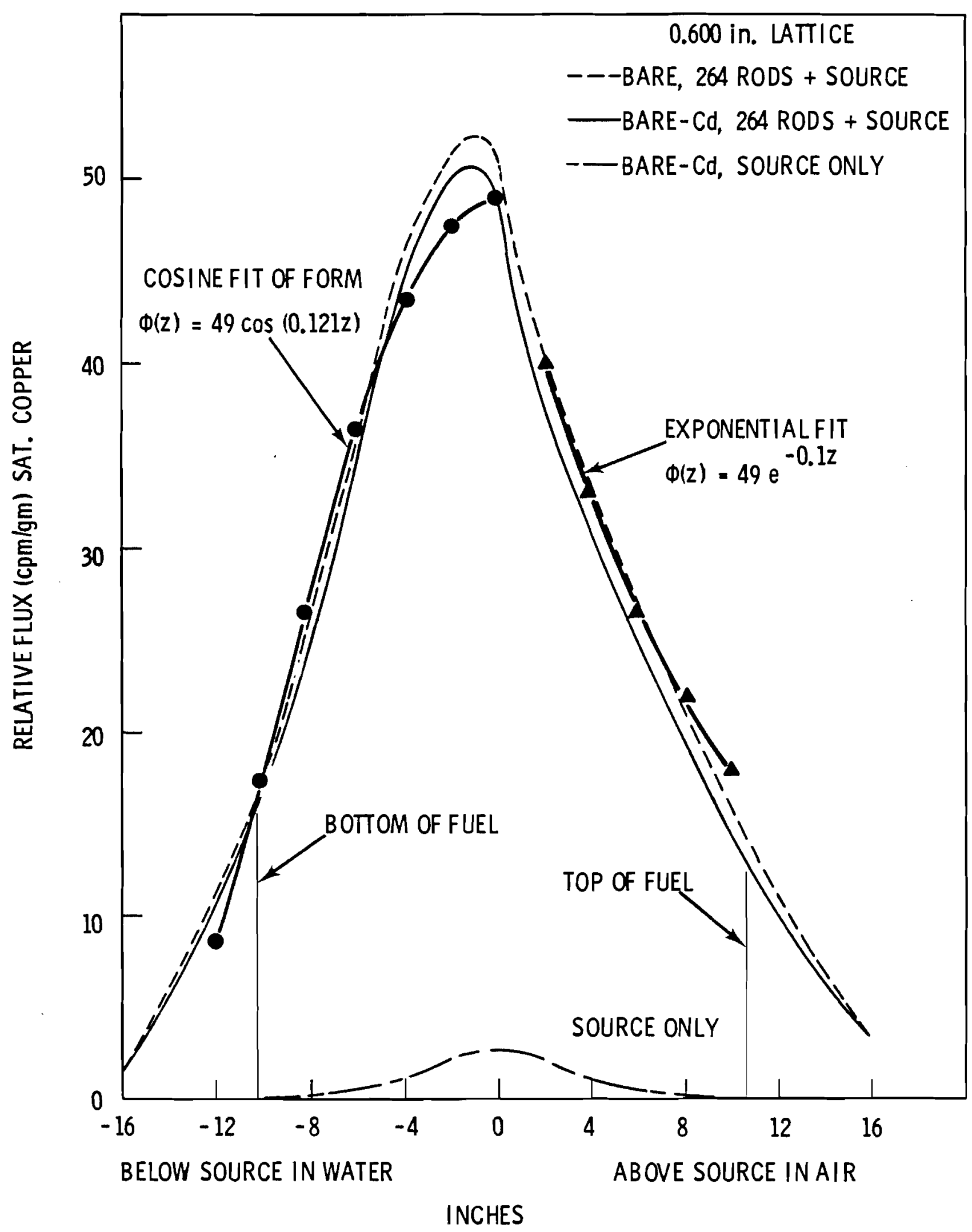

FIGURE 10. 
TABLE VIII.

RELATIVE RADIAL FLUX COMPARISON

(0.60 in. Lattice Spacing)

\begin{tabular}{|c|c|c|}
\hline Foil Position & $\begin{array}{c}\text { Relative Flux } \\
\text { Saturation Activity } \\
(\mathrm{cpm} / \mathrm{gm})\end{array}$ & $\frac{\phi \text { Center }}{\phi \text { Outside }}$ \\
\hline 1.8 in. Outside Fuel in Void & 13693 & 3.17 \\
\hline Center at Water/Void Interface & 43475 & \\
\hline 1.8 in. Outside Fuel in Water & 13685 & 3.18 \\
\hline
\end{tabular}


the outside fuel edge and one foil was centered in a 2 in. void tube whose center point was $~ 1.8$ in. away from the fuel. Another foil was, again, positioned in the center of the flux trap. The flux at the center was about 3.2 times the outside flux, and it is interesting to note, further, that the relative flux in both the void tube and water was nearly the same.

\section{Effect of Rod Removal From the Lattice Region}

For lattices of either a 0.55 or 0.60 in. spacing, the fuel assembly is undermoderated. The undermoderated lattice is required if the multiplier is to have a negative temperature coefficient. The removal of a fuel rod from the lattice creates a more moderated area within the lattice, which increases the reactivity; i.e., fuel rod removal from within the lattice region could cause the system to attain criticality. Table IX gives the increased effects of rod removal from approximately the mid-region of the loading. For the $0.55 \mathrm{in}$. lattice, a rod removed from the loaded region produces about the same effect on reactivity as a rod added to the outside of the lattice; in the $0.60 \mathrm{in}$. lattice, it would be equivalent to about a $1 / 2$ rod addition. Obviously, care must be taken to not unload from within the lattice region.

\section{Calculation of the Operation Loading}

The mathematical determination of the loading suggested for operation is shown in Table $X$. The number of fuel rods $(N)$ for $k_{\text {eff }}=0.985$ was determined for the system as it would used in operation; i.e., no credit was allowed for the source, added outside plates, void tubes, etc., that could be removed. This $N$ value was 257.9 rods. Reducing the number of rods to compensate for the temperature effect and the effect of $5 \mathrm{~g}^{235} \mathrm{U}$ in the central tube gives the operation loading of 252.3. Using this loading, limits would have to be placed on materials used in the outside radiation tubes and on fuel rod removal from the lattice region. 
TABLE IX.

WORTH OF ROD REMOVAL FROM LATTICE

\begin{tabular}{|c|c|c|c|c|}
\hline $\begin{array}{l}\text { Exp. } \\
\text { No. }\end{array}$ & $\begin{array}{l}\text { Lattice } \\
\text { Spacing }\end{array}$ & $\begin{array}{l}\text { Number of Inner } \\
\text { Rods Removed } \\
\end{array}$ & $\begin{array}{l}\text { Worth } \\
\text { (Rods) }\end{array}$ & $\begin{array}{c}\text { Worth } \\
\text { (Rods/Rod) } \\
\end{array}$ \\
\hline \multirow[t]{4}{*}{$004^{(2)}$} & 0.55 & 6 & 4.30 & 0.72 \\
\hline & 0.55 & 12 & 10.29 & 0.86 \\
\hline & 0.55 & 18 & 16.94 & 0.94 \\
\hline & 0.55 & 24 & 24.35 & 1.01 \\
\hline \multirow[t]{2}{*}{$019^{(3)}$} & 0.60 & 6 & 3.51 & 0.59 \\
\hline & 0.60 & 12 & 6.70 & 0.56 \\
\hline
\end{tabular}

(1) Number of rods equivalent on outside of lattice for each removed from within lattice region.

(2) With 3 in. void tube, 55 rod equivalent flux trap; rods removed from 5 th row.

(3) With 2 in. void tube $-1 / 2$-filled with water; 37 rod equivalent flux trap; rods removed from 4 th row. 


\section{TABLE $X$.}

TYPICAL CALCULATION OF AN OPERATION LOADING

(0.60 in. Lattice Spacing)

$N_{c}$ (2 in. Void Center Tube) $=271.4$

$\mathrm{N}_{\mathrm{c}}(2 \mathrm{in} .1 / 2 \mathrm{Filled} /$ Water $)=276.3$

Difference : $276.3-271.4=4.9$

$N\left(k_{\text {eff }}=0.985\right) \quad 254.5$ with 2 in. Void Center $+B F_{3}$

- 1.5 for $B F 3$

253.0

+4.9 for $1 / 2$ Full/Water

257.9

- 2.6 for Temperature

255.3

- 3.0 for Center Effect for Sample -

$\left(k_{\text {eff }}=0.981\right) \quad 252.3$

235u, (5.0 g max.), Graphite

Conditions:

1. Fissile material limit in center equivalent to $5 \mathrm{~g}^{235} \mathrm{U}$.

2. No correctionfor outside tube materials

Limit ${ }^{235} U$

Limit graphite and other low absorbtion scatters and/or distance

3. Any fuel rod removal must be from the outside of loaded region. 


\section{CONCLUSIONS}

1. Outside void radiation tubes have a large effect on reduction of reactivity. They should be flooded or moved away from the assembly.

2. Materials such as graphite (low absorption scatterers) increase reactivity in both the center and outside lattice regions when replacing either water or voids.

3. The reactivity worth of a fuel rod in the outer ring of the lattice, at the operational loading, is 0.00065 in terms of $k_{\text {eff }}$.

4. A temperature increase above $21^{\circ} \mathrm{C}$ increases reactivity by the equivalent of 2.6 fue 1 rods maximum.

5. One-third of a fuel element in the central radiation tube increases reactivity by the equivalent of about 4.4 fuel rods.

6. The source mockup with $200 \mathrm{~g}$ stainless steel causes a decrease in reactivity equal to 1.9 fue 1 rods.

7. A large reduction in reactivity was realized by pouring the 2 in. diameter center void tube full of $6 \mathrm{~g} / 1 \mathrm{iter}$ boric acid solution. This was equivalent to about -29 fuel tubes; however, the reactivity effect would be only about one-half this much in the multiplier, since its central tube is only halfway through the lattice region.

8. The operating loading must account for possible positive reactivity effects. Though attempts were made in design to optimize effects, some still remain. Temperature effects and positive effects from materials placed into the radiation tubes must be considered. The loading of the system must be reduced so that $k_{\text {eff }}$ will remain below the maximum allowed. The $k_{\text {eff }}$ for the recommended loading would be 0.981 , with no samples and at room temperature. 
9. Other effects causing reduced reactivity will make the multiplier less efficient; these include outside void tubes near lattice, stainless steel in source construction, and high neutron absorption materials in the irradiation tubes. Sample materials which are fissile or low absorption scatterers could increase reactivity.

10. The thermal neutron flux multiplication ( $M$ as defined on page 10) with the multiplier lattice at a $k_{\text {eff }}$ of 0.99 was found to vary from 20 (at the source position) to over 50 at a position $15 \mathrm{~cm}$ above the source. $M$ is, therefore, subject to some interpretation. It might be more meaningful to consider the average flux increase (due to multiplication) over a finite volume about the source or to consider the average buildup in thermal flux over the region wherein the materials would be irradiated.

11. The flux relationship on the inside near the $3.7 \mu \mathrm{g} C f$ source is about 3.2 times that outside the lattice at about $1.8 \mathrm{in}$. from the outside tube. ACKNOWLEDGEMENT

This report summarizes criticality studies conducted recently on a neutron multiplier lattice by Battelle Pacific Northwest Laboratories for the Energy Research and Development Administration under Contract E(45-1):1830. Acknowledgement is also made of George Rieck and Victor Epperly for their interest in, and suggestions for obtaining, the most useful data; also of J. H. Smith for assistance in experimental preparation and data analysis and of Donna Andersen for assistance in obtaining reproducible curves and figures and in preparation of this report. 


\section{REFERENCES}

1. L. E. Hansen, N. A. Wogman, R. W. Perkins and E. D. Clayton, "Subcritical Multiplication of Californium-252 Neutrons and Its Applications," Nuclear Technology, vol. 15, September 1972.

2. S. H. Levine, "Fundamentals of Neutron Multipliers, Californium-252." Utilization Meeting, November 4-6, 1975, San Diego.

3. R. J. Hall and H. G. Rieck, Jr., "Preliminary Safety Analysis Report for the PNL Neutron Multiplier Facility," BNWL-B-341, January 1974.

4. R. J. Ha11, "Engineering Design Prints Neutron Multiplier," H-3-32787 Sh 1-4, H-3-32788 Sh 1 and 2, H-3-32789.

5. E. Garelis and J. L. Russe11, "Theory of Pulsed Neutron Source Measurements," Nuclear Science and Engineering, 16, 263, 1963.

6. T. Gozani, P. DeMarmels, T. Hurlimann and H. Winkler, "On the Modified Pulsed Source Techniques," IAEA, Karlsruhe Symposium on Pulsed Neutron Research, 1965.

7. W. J. Pierce, "Nuclear Radiation Detection," McGraw-Hill, New York, p. $336,1964$.

8. C. W. Tuttle, "Quantitative and Qualitative Analysis through Neutron Activation," Nuclear Chicago Corp., Technical Bulletin; No. 10, 1964. 


\section{DISTRIBUTION}

No. of

Copies

OFFSITE

ERDA Chicago Patent Group

U.S. Energy Research and Development Administration Chicago Operations Office 9800 South Cass Avenue Argonne, I11inois 60439

1

A. A. Churm

Division of Biomedical and Environmental Research U. S. Energy Research and Development Administration Washington, D.C. 20545

1 R. W. Wood

27

ERDA Technical Information Center

ONSITE-HANFORD

ERDA Richland Operations Office

F. R. Standerfer

B. J. Melton

H. A. House

Battelle-Northwest

E. D. Clayton

N. E. Carter

S. R. Bierman

B. M. Durst

B. W. Howes

R. C. Lloyd

J. M. Nielsen

G. H. Rieck

V. P. Epperly

E. I. Wandling

Technical Information Files

Technical Publications 